\title{
PENERAPAN KONSEP LINE BALANCING UNTUK MENCAPAI EFISIENSI KERJA YANG OPTIMAL PADA SETIAP STASIUN KERJA PADA PT. HM. SAMPOERNA Tbk.
}

\author{
Rony Prabowo \\ Fakultas Teknologi Industri ITATS, Jl. Arief Rachman Hakim 100 Surabaya \\ Email: rony_prabowomt@yahoo.co.id
}

\begin{abstract}
Mechanical balancing is required in the production process, without balancing the work station so the production process will not be effective and efficient. In the production process of PT. HM. Sampoerna Tbk. faced with the problems of balancing the lack of efficiency at the work station, so it is planned to determine the optimal production line so that the load on each work station will be more evenly and reduce idle time. The method used is the method of measurement of working time with stop watch and the method of weighting positions (Method Ranked Positional Weight). The data analyzed is the time required by the operator to complete the production of cigarettes and the number of output rate to the average product produced to establish the ideal cycle time. Then both the above data were analyzed using the method of weight position, and came up production time and efficiency optimal trajectory and optimal work station anyway. The results of the analysis suggest that the use of line balancing methods, companies can achieve efficiency of $68.54 \%$ trajectory and reduce the imbalance or balance delay amounted to $42.02 \%$ from $73.48 \%$ to $31.46 \%$ and total production target 240box/day can be met.
\end{abstract}

Keywords: balance, station, efficiency, weight

\begin{abstract}
ABSTRAK
Teknik keseimbangan lintasan diperlukan dalam proses produksi. Tanpa adanya keseimbangan lintasan dalam stasiun kerja maka proses produksi tidak akan berjalan secara efektif dan efisien. Dalam proses produksinya, PT. HM. Sampoerna Tbk. dihadapkan pada permasalahan keseimbangan lintasan yaitu kurangnya efisiensi pada stasiun kerja, sehingga direncanakan untuk menentukan lintasan produksi yang optimal sehingga pembebanan pada setiap stasiun kerja akan lebih merata dan mengurangi waktu menganggur. Metode yang digunakan adalah metode pengukuran waktu kerja dengan jam henti (stop watch) dan metode bobot posisi (Method Ranked Positional Weight). Data yang dianalisis adalah waktu yang diperlukan oleh operator untuk menyelesaikan produksi rokok dan jumlah output rate untuk produk rata-rata yang dihasilkan untuk menetapkan waktu siklus ideal. Kedua data tersebut kemudian dianalisis dengan menggunakan metode bobot posisi, hingga didapatkan waktu produksi dan efisiensi lintasan yang optimal serta stasiun kerja yang optimal pula. Hasil analisis menyatakan bahwa dengan penggunaan metode keseimbangan lintasan, perusahaan dapat mencapai efisiensi lintasan sebesar 68,54\% dan mengurangi ketidakseimbangan (balance delay) sebesar 42,02\% dari 73,48\% menjadi 31,46\% Dan target produksi sebanyak 240 box/hari dapat terpenuhi.
\end{abstract}

Kata kunci: keseimbangan, lintasan, efisiensi, bobot

\section{PENDAHULUAN}

Pertumbuhan industri yang mengalami kemajuan pesat bagi pihak industri merupakan indikator semakin meningkatnya pesaing yang ada, baik secara kualitas maupun kuantitas produksi. Dengan adanya persaingan itu, maka pihak industri dituntut untuk selalu meningkatkan produktivitas dan efisiensi produksi. Hal ini dimaksudkan untuk meningkatkan daya saing bagi produk itu sendiri di pasaran, karena dengan semakin meningkatnya produktivitas dan efisiensi produksi maka diharapkan industri tersebut mampu menekan biaya produksi. Selain itu, keuntungan yang diperoleh industri tersebut juga meningkat, tidak terkecuali PT. HM. Sampoerna yang merupakan badan usaha yang memproduksi rokok. 
PT. HM. Sampoerna Tbk. yang berlokasi tersebar di beberapa daerah atau wilayah, di dalam aktivitasnya yaitu memproduksi rokok (sigaret kretek tangan dan sigaret kretek mesin) memiliki jumlah tenaga kerja yang sangat besar. Dalam meghasilkan rokok, setiap tenaga kerja ditargetkan untuk menghasilkan sekian ribu batang rokok berdasarkan standar yang dberikan oleh pihak perusahaan. Sistem kerja yang diterapkan oleh pihak perusahaan dalam memproduksi rokok adalah sistem borongan, mulai proses linting sampai proses pengebalan. Melihat kondisi seperti ini, diperlukan suatu keseimbangan lintasan agar dapat diketahui berapa jumlah tenaga kerja pada setiap stasiun kerja.

Memperhatikan peranannya yang sangat strategis, perusahaan tersebut diharapkan mampu mempertahankan kelangsungan hidupnya dan mampu menjadi pusat pengembangan produksi rokok di dalam negeri. Dalam waktu mencapai tujuan tersebut, ketepatan waktu proses produksi rokok sangatlah penting sehingga perusahaan dapat memenuhi target produksi yang diinginkan tepat pada waktunya.

Masalah yang dihadapi oleh PT. HM. Sampoerna Tbk, di lokasi Taman Sampoerna Surabaya dalam menghasilkan rokok sering terjadi hambatan di dalam lintasan proses produksi rokok. Hambatan tersebut disebabkan ketidakseimbangan lintasan produksi di antara stasiun kerja pada proses produksi. Tanpa adanya keseimbangan lintasan di dalam stasiun kerja, maka proses produksi tidak akan berjalan secara efektif dan efisien, karena pada beberapa stasiun kerja yang mempunyai station line yang besar akan terdapat antrian komponen yang akan diproses. Di pihak lain, ada stasiun kerja yang mempunyai station line yang kecil sehingga terjadi idle. Dengan demikian, proses produksi tidak berjalan dengan lancar dan optimalisasi hasil dan sumber daya tidak tercapai.

Berdasarkan latar belakang dan perumusan masalah tersebut maka dalam penelitian ini akan dibahas tentang bagaimana merencanakan sistem kerja di pabrik rokok PT. HM. Sampoerna Tbk untuk mengoptimalkan pengaturan work station didasarkan pada waktu siklus dan precedence constrain, sehingga efisiensi lintasan produksinya meningkat.

Penelitian ini bertujuan untuk memperoleh suatu lintasan produksi yang lebih baik daripada kondisi saat ini dengan beban kerja yang seimbang dan penggunaan fasilitas produksi yang ada seoptimal mungkin. Selain itu, penelitian ini juga mencoba mengurangi perbedaan waktu kerja antarstasiun kerja dan memperbaiki atau meminimalkan waktu menganggur dan meningkatkan efisiensi lintasan.

\section{TINJAUAN PUSTAKA}

\section{Pengukuran Waktu Kerja}

Penelitian kerja dan analisis metode kerja pada dasarnya akan memusatkan perhatian pada bagaimana suatu amacam pekerjaan akan diselesaikan. Dengan mengaplikasi prinsip dan teknik pengaturan cara kerja yang optimal dalam sistem kerja tersebut, maka akan dapat alternatif metode pelaksanaan kerja yang dianggap memberi hasil yang paling efektif dan efisien. Suatu pekerjaan akan dikatakan diselesaikan secara efisien apabila waktu penyelesaian berlangsung paling singkat [1]. Untuk menghitung waktu baku (standard time) penyelesaian pekerjaan guna memilih alternatif metode kerja yang terbaik, maka perlu diterapkan prinsip-prinsip dan teknik-teknik pengaturan waktu kerja (work measurement or time study). Waktu baku ini sangat diperlukan terutama sekali untuk: (1) Man Power Planing (perencanaan kebutuhan tenaga kerja); (2) Estimasi biaya-biaya untuk upah karyawan/pekerja; (3) Penjadwalan produksi dan penganggaran; (4) Perencanaan sistem pemberian bonus dan insentif bagi karyawan/pekerja yang berprestasi; Indikasi keluaran yang mampu dihasilkan oleh seorang pekerja; dan (5) Menyeimbangkan lintasan produksi (line balancing) [2].

Pada garis besarnya, teknik-teknik pengukuran waktu kerja dapat dikelompokkan ke dalam dua bagian [3] yaitu: (1) Pengukuran waktu kerja secara langsung. Pengukuran dilaksanakan secara langsung yaitu ditempatkan dimana pekerja diukur, dilaksanakan dengan menggunakan jam henti (stopwatch time study) dan menggunakan sampling kerja (work sampling); (2) Pengukuran waktu 
kerja secara tidak langsung. Merupakan cara tidak langsung dalam melakukan perhitungan waktu kerja tanpa si pengamat harus berada di tempat pekerjaan yang harus diukur.

\section{Definisi Keseimbangan Lintasan (Line Balancing)}

Keseimbangan lintasan atau line balancing adalah suatu metode penugasan sejumlah pekerjaan ke dalam stasiun kerja yang saling berkaitan dalam satu lintasan produksi sehingga terdapat kesamaan waktu penyelesaian stasiun pada setiap stasiun kerja [4]. Apabila penugasan masing-masing pekerjaan ke dalam stasiun kerja menghasilakan waktu stasiun yang hampir sama, maka dapat dikatakan telah tercapai keseimbangan sempurna dan aliran produksi pasti lancar. Pengelompokan tugas-tugas yang akan menghasilkan keseimbangan lintasan produksi memberikan informasi tentang kinerja waktu dari tugas tersebut, kebutuhan-kebutuhan pendahuluan yang menentukan urutan-urutan yang fleksibel, dan tingkatan output yang diinginkan atau siklus waktu per unit [5].

Pada dasarnya, keseimbangan lintasan terdiri atas dua bagian penting [6], yaitu: (1) Tempat-tempat kerja atau mesin-mesin; dan (2) Pekerja-pekerja yang melaksanakan tugas tertentu pada tempat kerja atau mesin tersebut.

Beberapa keuntungan yang dapat diperoleh dari perencanaan lintasan produksi yang baik [7] adalah: (1) Pengerjaan operasi yang serentak untuk setiap operasi dikerjakan pada saat yang sama di seluruh lintasan produksi; (2) Aliran benda kerja atau material diukur dengan kecepatan produksi dan bukan oleh kecepatan spesifik; (3) Jarak perpindahan material yang minimum dapat diperoleh dengan mengatur susunan dan tempat kerja; (4) Pembagian tugas terbagi secara merata yang disesuaikan dengan keahlian masing-masing pekerja sehingga tenaga kerja dapat dimanfaatkan secara efisien; (5) Gerakan benda kerja tetap sesuai dengan set up dari lintasan; dan (5) Waktu minimum untuk menyelesaikan proses produksi dapat diperoleh.

Berdasarkan karakteristik proses pengerjaan yang dilakukan, lintasan keseimbangan dapat dibedakan ke dalam dua bagian [8], yaitu: (1) Lintasan Perakitan (assembly line) yaitu suatu produksi yang terdiri atas sejumlah operasi perakitan (assembly operation) yang dikerjakan di berbagai tempat; (2) Lintasan Pabrikasi (fabrication line), yaitu suatu lintasan produksi yang terdiri atas sejumlah operasi pengerjaan yang bersifat membentuk atau mengubah sifat-sifat atau kimia dari suatu benda kerja yang melewati lintasan tersebut.

Untuk mendapatkan lintasan produksi yang baik maka harus pula diperhatikan syarat-syarat [9] sebagai berikut: (1) Jumlah atau volume produksi harus dapat menutupi biaya set up dari lintasan; (2) Kontinuitas dari aliran benda kerja pada lintasan harus dijaga; dan (3) Keseluruhan waktu kerja untuk masing-masing operasi sedapat mungkin sama.

\section{Parameter Keseimbangan Lintasan}

Terdapat beberapa batasan yang perlu dikatahui dalam memecahkan persoalan tersebut, yakni:

\section{Elemen Kerja Rasional Minimum (Minimum Rational Work Element)}

Elemen kerja rasional minimum adalah elemen kerja terkecil dimana pekerjaan tidak dapat dipisahpisah lagi. Waktu yang dibutuhkan untuk melengkapi satu elemen kerja dilambangkan dengan $T_{e j}$, dengan $j$ adalah elemen kerja ke- $j$ dari $T_{e}$ elemen kerja yang membentuk keseluruhan pekerjaan. Waktu $T_{e j}$ dianggap tetap atau konstan. Asumsi ini mungkin lebih tepat untuk pekerjaan yang dilakukan secara otomatis. Dalam operasi yang bersifat manual, waktu yang dibutuhkan pada kenyataan sangat bervariasi dari satu siklus ke siklus lainya. Asumsi lain bahwa nilai $T_{e j}$ bersifat aditif yang berarti bahwa untuk mencari waktu dua elemen kerja atau lebih dapat dijumlahkan. $T_{e j}=$ Waktu yang dipergunakan untuk mengerjakan elemen kerja ke-ej.

\section{Isi Keseluruhan Pekerjaan (Total Work Content)}

Isi keseluruhan pekerjaan adalah jumlah dari seluruh elemen kerja yang harus dilaksanakan pada lintasan. Persamaannya adalah:

$$
T_{w c}=\sum T_{e j}
$$


dengan $T_{w c}$ adalah waktu yang dipergunakan untuk menyelesaikan seluruh pekerjaan (work content).

\section{Waktu Proses Stasiun Kerja (Work Station Process Time)}

Waktu proses stasiun kerja adalah penjumlahan dari waktu elemen-elemen kerja tersebut. Atau dengan kata lain, waktu yang dibutuhkan untuk menyelesaikan proses pada suatu stasiun kerja. Dapat pula diartikan sebagai jumlah waktu yang digunakan untuk mengerjakan seluruh elemen kerja pada stasiun tersebut. Persamaannya adalah:

$$
\sum T_{s i}=\sum T_{e j}
$$

dengan $T_{s i}$ adalah work station process time.

\section{Waktu Siklus (Cycle Time)}

Waktu siklus $\left(T_{c}\right)$ adalah interval waktu antara komponen keluar masuk dari lintasan produksi atau waktu menyelesaikan satu unit produk mulai dari awal sampai akhir, maka $T_{c} \leq E / \mathrm{Rp}$. Harga minimum yang tidak mungkin untuk $T_{c}$ ditentukan oleh stasiun yang paling lambat, yaitu stasiun yang mempunyai harga $T_{s i}$ yang paling besar, ini berarti $T_{c} \geq \operatorname{Max} T_{s i}$.

Jika $T_{c}=$ Max $T_{s i}$, maka akan terjadi waktu menganggur pada stasiun kerja yang mempunyai harga $T_{s i}$ yang lebih kecil daripada $T_{c}$. Syarat lain adalah waktu siklus tidak boleh lebih kecil dari waktu masing-masing elemen kerja yang manapun. Secara sistematis dapat dituliskan: $T_{c} \geq T_{e j}$ (untuk semua $j=1,2,3, \ldots, n)$.

\section{Delay Time}

Delay time adalah perbedaan antara stasiun dengan waktu siklus dimana besarnya waktu stasiun kurang dari waktu siklus yang mengakibatkan terjadinya waktu menganggur atau disebut Idle Time.

\section{Penundaan Seimbang (Balance Delay)}

Penundaan seimbang disebut juga balancing loss, digunakan untuk mengukur ketidakefisienan lintasan produksi atau perakitan akibat waktu idle yang disebabkan alokasi stasiun kerja yang tidak tepat.

\section{Efisiensi Seimbang (Balance Efficiency)}

Balance efficiency dapat dihitung dengan persamaan: $\eta=1-d$. Suatu keadaan seimbang sempurna (perfect balance) adalah suatu keadaan dimana balance delay sama dengan nol.

\section{Precedence Diagram}

Dalam suatu lintasan perakitan biasanya muncul dua kondisi [10], yaitu: (1) Tidak adanya ketergantungan dari komponen-komponen dalam proses perakitan setiap komponen mempunyai keseimbangan untuk dilaksanakan pertama kalinya, dalam arti komponen tersebut tidak ada hubungan ketergantungan aktivitas; dan (2) Apabila komponen terebut adalah hasil dari proses yang mendahului atau hasil perakitan dari komponen-komponen sebelumnya. Di sini dinyatakan batasan precedence untuk pengerjaan komponen-komponen.

Precedence Diagram adalah gambaran secara sistematis yang mempertimbangkan uruturutan suatu proses pengerjaan dari keseluruhan operasi pengerjaan tersebut dengan tujuan untuk memudahkan pengawasan, evakuasi, serta perencanaan aktivitas-aktivitas yang terkait di dalamnya. Menurut [5], biasanya, precedence untuk $p$ ditandai dengan: (1) Simbol linkaran (node) atau huruf di dalamnya untuk mempermudah identifikasi dari suatu proses operasi yang membedakan aktivitas yang satu dengan aktivitas yang lain; (2) Tanda panah menunjukkan ketergantungan dari urutan proses operasi. Dalam hal ini operasi yang berada pada pangkal panah berarti mendahului 
operasi kerja yang ada pada ujung anak panah; (3) Angka di atas simbol lingkaran adalah waktu standart (Ws) yang dibutuhkan untuk menyelesaikan setiap operasi. Sehingg dengan cara ini akan terlihat dua macam hubungan yaitu: hubugan seri (berurutan) dan hubungan paralel (mutually independent).

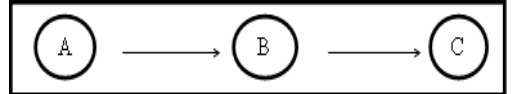

Gambar 1. Hubungan seri (berurutan)

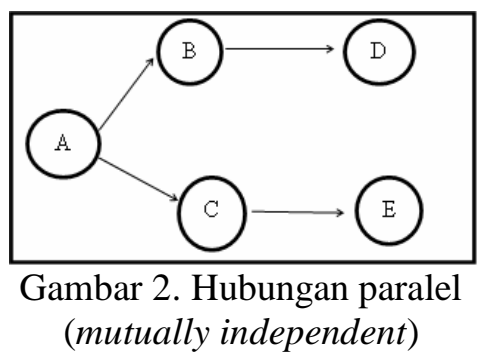

(mutually independent)

\section{Maksud dan Tujuan Keseimbangan Lintasan}

Menurut [11], tujuan dari penerapan keseimbangan lintasan dalam pelaksanaan proses produksi adalah: (1) Pembebanan yang seimbang disetiap stasiun kerja dengan kecepatan produksi yang diinginkan; (2) Beban stasiun kerja diukur dengan besaran waktu; (3) Penurunan jumlah stasiun kerja; (4) Pengurangan jumlah waktu menganggur (idle time) di setiap stasiun kerja; dan (5) Sedangkan maksud dari penerapan keseimbangan lintasan adalah untuk memperoleh efisiensi kerja yang tinggi dan mencapai targer produksi sesuai dengan rencana produksi.

\section{Metode-Metode Keseimbangan Lintasan}

Aliran produksi di dalam proses perakitan dan produksi pada umumnya dibagi menjadi beberapa kelompok elemen kerja di dalam stasiun-stasiun kerja yang berbeda [1]. Tiap-tiap stasiun kerja mempunyai beban kerja dan waktu operator yang berbeda pula, sehingga kelancaran dan kemungkinan mencapai target produksi yang telah ditetapkan bertambah kecil. Terdapat beberapa metode yang dapat digunakan untuk menyeimbangkan lintasan perakitan produksi [3] yaitu: (1) Metode Analitis. Metode ini merupakan metode dengan pendekatan matematis yang akan memberikan solusi optimal tetapi memerlukan perhitungan yang besar dan rumit, misalnya dengan menggunakan linier programing dan dynamic programing; (2) Metode Heuristik. Pada awalnya, metode-metode line balancing dikembangkan dengan pendekatan sistematis. Akan tetapi, metode ini tidak sistematis dan tidak ekonomis, sehingga metode-metode tersebut akan sulit untuk bisa menyelesaikan persoalan perakitan yang melibatkan operasi pengerjaan dalam jumlah besar.

Penyelesaian masalah keseimbangan lintasan dengan menggunakan metode heuristik ada dua macam [9], yaitu:

1. Ranked Positional Weight (RPW) atau metode bobot posisi merupakan metode heuristik. Metode ini mengutamakan waktu elemen kerja yang terpanjang. Elemen kerja tersebut akan diprioritaskan terlebih dahulu untuk ditempatkan dalam stasiun kerja yang lain yang mewakili waktu element yang lebih rendah. Proses ini dilakukan dengan memberikan bobot (rank). Bobot ini diberikan pada setiap elemen pekerjaan dengan memperhatikan precedence diagram. Dengan demikian, elemen pekerjaan yang memiliki ketergantungan terbesar akan memiliki bobot yang besar sehingga lebih diprioritaskan. Langkah-langkah yang dilakukan dalam metode ini adalah sebagai berikut: (a) Membuat gambar urutan elemen kerja dalam bentuk network (precedence diagram); (b) Menentukan waktu kerja yang dipergunakan untuk setiap elemen kerja tersebut; (c) Menghitung bobot posisi. Bobot posisi adalah waktu dari elemenelemen kerja yang mengikutinya ditambah dengan waktu elemen kerja itu sendiri; (d) Menyusun daftar kerja menurut besarnya posisi masing-masing; (e) Menentukan waktu siklus (cycle time) yaitu waktu yang dipergunakan untuk stasiun kerja yang diambil dari waktu kerja yang terbesar atau terlama; (f) Menentukan jumlah stasiun kerja minimum yang sebaikanya ada, dengan menggunakan persamaan:

$$
n=\frac{T_{w c}}{T_{c}}
$$


(g) Menentukan pembagian tugas pada masing-masing stasiun kerja berdasarkan daftar elemen kerja dan besarnya cycle time; dan (h) Memperbaiki pambagian tugas pada langkah point (g). Sehingga, dicapai efisiensi stasiun kerja/efisiensi lintasan yang optimum.

$$
L E=\frac{T_{w c}}{n \times T_{c}}
$$

Pada metode bobot posisi ini pemecahannya tidak memerlukan waktu yang sangat lama, bersifat praktis dan sederhana dan tidak membutuhkan biaya yang banyak.

2. Largest - Candidate Rule. Metode ini adalah metode yang paling mudah dimengerti. Pemilihan elemen pekerjaan yang baik dikerjakan pada sebuah stasiun kerja yang didasarkan pada nilai waktu elemen kerjanya $\left(T_{e}\right)$. Langkah-langah yang dilaksanakan dalam metode ini adalah: (a) Buat precedence diagram yang membagi elemen-elemen pekerjaan dalam kolom-kolom vertikal; (b) Tentukan wilayah precedence dari kiri ke kanan. Gambar lagi jaringan tersebut, kemudian kumpulkan semua pekerjaan ke wilayah precedence yang terakhir. Hal ini akan memberikan kepastian bahwa pekerjaan dengan sedikit ketergantungan akan dipertimbangkan menjadi paling akhir dalam jadwal; (c) Dalam setiap wilayah precedence, urutkan waktu pengerjaan dari yang maksimum ke minimum. Hal ini memberikan kepastian pekerjaan yang terbesar akan dipertimbangkan terlebih dahulu, memberikan kesempatan terakhir untuk memperoleh kombinasi yang lebih baik dengan pekerjaan-pekerjaan yang kebih kecil; dan (d) Tempatkan pekerjaan-pekerjaan dengan mengikuti tata urutan.

\section{METODE}

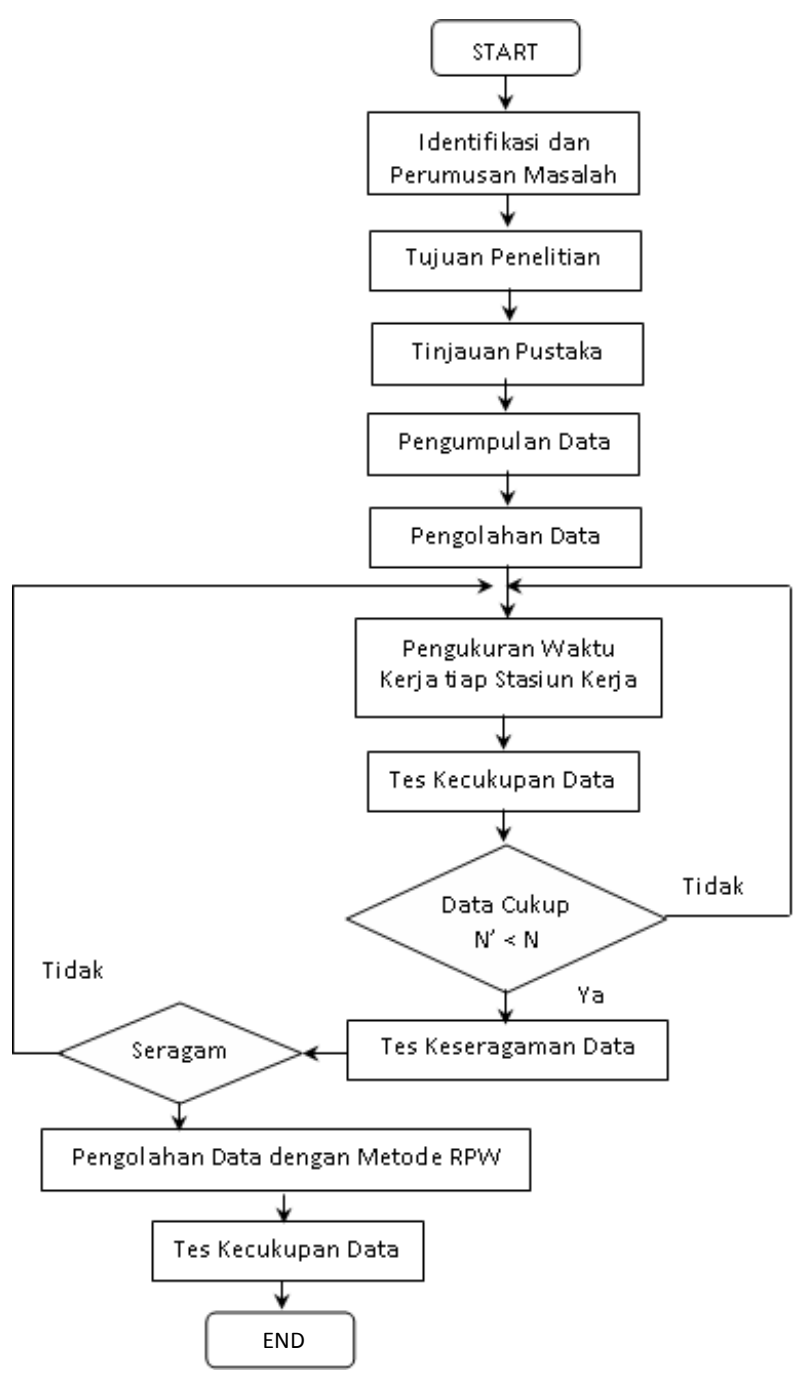

Gambar 3. Metodologi penelitian 


\section{Identifikasi dan Perumusan Masalah}

Adanya ketidakseimbangan beban kerja dan pekerja (operator) pada masing-masing stasiun kerja menyebabkan waktu penyelesaian antarstasiun tidak sama. Hal ini terlihat pada keadaan dimana pada satu stasiun terjadi penumpukan pekerjaan padahal pekerjaan tersebut berasal dari stasiun kerja yang lain.

\section{Tujuan Penelitian}

Untuk menyeimbangkan lintasan proses pembuatan rokok melalui perhitungan penyeimbangan lintasan dan pencapaian efisiensi stasiun kerja serta penetapan jumlah stasiun kerja sehingga meminimalkan waktu menganggur.

\section{Pengolahan Data}

1. Menghitung waktu baku

2. Menghitung waktu rata-rata tipa stasiun kerja

3. Melakukan penyeimbangan lintasan menggunakan metode ranked positional weights (RPW)

\section{Kesimpulan dan Saran}

Dari hasil pengolahan data alternatif pemecahan masalah dan analisis alternatif pemecahan masalah maka dapat ditarik kesimpulan dan pemberian saran pada pemilik perusahaan.

\section{HASIL DAN PEMBAHASAN}

\section{Analisa dan Pengolahan Data}

Pada jalur produksi sigaret kretek tangan Dji Sam Soe, proses produksi terjadi dalam lima stasiun kerja. Urutan proses produksi dimulai dari proses penggilingan sampai ke proses pengebalan. Tabel 1 menunjukkan urutan proses produksi.

Tabel 1. Urutan proses produksi sigaret kretek tangan

\begin{tabular}{ll}
\hline No. & Stasiun Kerja \\
\hline 1 & Giling \\
2 & Gunting \\
3 & Packing \\
4 & Bandrol \\
5 & Proses Ball \\
\hline
\end{tabular}

\section{Elemen Kerja Setiap Stasiun Kerja}

Stsiun kerja yang ada pada jalur produksi ini berjumlah lima stasiun kerja. Pekerjaan pada setiap stasiun kerja merupakan pekerjaan manual, tidak ada yang dikerjakan secara otomatis oleh mesin khusus. Elemen-elemen kerja pada setiap stasiun kerja dapat dilihat pada Tabel 2.

Tabel 2. Daftar elemen kerja pada jalur produksi dan jumlah operator

\begin{tabular}{llll}
\hline Stasiun Kerja & No. & Elemen Kerja & Jumlah Operator \\
\hline 1 & 1 & Giling Tembakau pada unit 1 & 391 \\
& 2 & Giling Tembakau pada unit 3 & 366 \\
& 3 & Giling Tembakau pada unit 4 & 339 \\
\hline 2 & 4 & Gunting sigaret batangan pada unit 1 & 132 \\
& 5 & Gunting sigaret batangan pada unit 3 & 117 \\
& 6 & Gunting sigaret batangan pada unit 4 & 110 \\
\hline 3 & 7 & Pengepakan Batangan & 223 \\
\hline 4 & 8 & Pemberian bandroll pada Pak & 41 \\
& 9 & Masukkan Pak Rokok pada kotak Slop & 41 \\
\hline
\end{tabular}




\begin{tabular}{llll}
\hline Stasiun Kerja & No. & Elemen Kerja & Jumlah Operator \\
\hline 5 & 10 & Pengepresan dalam bentuk lempengan \& ball & 17 \\
& 11 & Memasukan hasil press dalam kardus box & 17 \\
\hline
\end{tabular}

\section{Data Waktu Siklus untuk Setiap Elemen Kerja}

Dalam pengukuran waktu kerja pada setiap elemen kerja, pengambilan data dilakukan secara berulang-ulang (repetitive timing) sebanyak lima belas kali. Hasil pengukuran tersebut dapat dilihat pada Tabel 3 .

\section{Penetapan Waktu Siklus}

Waktu siklus adalah waktu pengamatan rata-rata dari suatu pekerjaan yang digunakan untuk menghitung waktu normal. Besarnya waktu siklus elemen kerja 3 adalah:

$$
W s=\frac{\sum X}{N}=\frac{104,9}{15}=6,9 \text { detik }=0,115 \text { menit }
$$

\section{Menentukan Waktu Baku}

Setelah diketahui waktu nornal dan waktu longgar maka dapat dicari waktu bakunya yaitu:

$$
W b=W n \times \frac{100 \%}{100 \%-\% \text { Allowance }}=6,8 \times \frac{100 \%}{100 \%-34 \%}=10,3 \text { detik }=0,17 \text { menit }=0,003 \mathrm{jam}
$$

\begin{tabular}{|c|c|c|c|c|c|c|c|c|c|c|c|c|c|c|c|}
\hline \multirow{2}{*}{$\begin{array}{l}\text { Elemen } \\
\text { kerja }\end{array}$} & \multicolumn{15}{|c|}{ Waktu Pengamatan (detik) } \\
\hline & 1 & 2 & 3 & 4 & 5 & 6 & 7 & 8 & 9 & 10 & 11 & 12 & 13 & 14 & 15 \\
\hline 1 & 6,3 & 6,5 & 6,2 & 7,1 & 7,1 & 6,3 & 6,4 & 6,6 & 5,9 & 6,4 & 6,2 & 5,8 & 5,7 & 6,2 & 6,3 \\
\hline 2 & 6,5 & 6,5 & 6,3 & 5,8 & 5,7 & 6,3 & 5,9 & 6,5 & 6,3 & 6,6 & 5,7 & 6,0 & 6,2 & 6,3 & 5,8 \\
\hline 3 & 6,6 & 6,5 & 7,2 & 6,9 & 7,4 & 7,2 & 6,8 & 6,9 & 7,2 & 6,7 & 7,4 & 6,8 & 6,6 & 7,2 & 7,2 \\
\hline 4 & 3,2 & 2,6 & 2,7 & 2,9 & 3,1 & 3,2 & 3,3 & 2,5 & 2,6 & 2,8 & 3,2 & 2,5 & 3,1 & 2,7 & 2,9 \\
\hline 5 & 2,5 & 2,7 & 2,9 & 2,6 & 3,1 & 2,7 & 2,9 & 3,2 & 2,7 & 2,5 & 2,5 & 2,9 & 2,5 & 3,1 & 3,2 \\
\hline 6 & 2,4 & 2,5 & 2,7 & 2,6 & 2,9 & 3,2 & 3,0 & 3,2 & 2,9 & 2,7 & 2,6 & 2,7 & 3,2 & 3,1 & 3,2 \\
\hline 7 & 15,5 & 15,7 & 16,2 & 17,4 & 16,5 & 17,5 & 15,9 & 16,8 & 15,7 & 15,6 & 15,9 & 16,8 & 16,9 & 17,3 & 16,7 \\
\hline 8 & 1,6 & 1,4 & 1,3 & 1,4 & 1,5 & 1,4 & 1,6 & 1,5 & 1,6 & 1,6 & 1,3 & 1,6 & 1,5 & 1,4 & 1,3 \\
\hline 9 & 12,8 & 12,8 & 123,6 & 14,1 & 13,5 & 14,5 & 15,7 & 13,2 & 15,6 & 13,4 & 16,2 & 15,7 & 13,8 & 14,7 & 13,3 \\
\hline 10 & 123,3 & 119,4 & 126,6 & 123,6 & 131,1 & 132,2 & 127,2 & 129,3 & 119,7 & 117,9 & 123,2 & 119,2 & 118,3 & 130,2 & 133,3 \\
\hline 11 & 89,2 & 85,5 & 90,5 & 85,7 & 84,4 & 91,1 & 82,6 & 91,3 & 84,3 & 79,6 & 80,5 & 83,7 & 87,5 & 90,2 & 90,5 \\
\hline
\end{tabular}

Tabel 3. Data waktu siklus tiap elemen kerja

\section{Analisis Kondisi Awal Perusahaan}

Tabel 4. Susunan stasiun kerja pada kondisi awal

\begin{tabular}{lllrr}
\hline $\begin{array}{l}\text { Stasiun } \\
\text { Kerja }\end{array}$ & $\begin{array}{l}\text { Elemen } \\
\text { Kerja }\end{array}$ & Penjelasan Elemen Kerja & $\begin{array}{r}\text { Waktu Baku } \\
(W b) \text { dt. }\end{array}$ & $\begin{array}{c}\text { Waktu Siklus } \\
(W s) \text { dt. }\end{array}$ \\
\hline 1 & 1 & Giling Tembakau pada unit 1 & 9,5 & \\
& 2 & Giling Tembakau pada unit 3 & 9,1 & \\
& 3 & Giling Tembakau pada unit 4 & 10,3 & 28,9 \\
\hline 2 & 4 & Gunting sigaret batangan pada unit 1 & 3,5 & \\
& 5 & Gunting sigaret batangan pada unit 3 & 3,4 & \\
& 6 & Gunting sigaret batangan pada unit 4 & 3,5 & 10,4 \\
\hline 3 & 7 & Pengepakan Batangan & 21,3 & 21,3 \\
\hline 4 & 8 & Pemberian bandroll pada Pak & 1,9 & \\
& 9 & Masukkan Pak Rokok pada kotak Slop & 18,5 & 20,4 \\
\hline 5 & 10 & Pengepresan dalam bentuk lempengan \& ball & 147 & \\
& 11 & Memasukan hasil press dalam kardus box & 101,4 & 248,4 \\
\hline
\end{tabular}


Tabel 5. Waktu siklus tiap stasiun kerja

\begin{tabular}{lrl}
\hline Stasiun ke & Waktu siklus (dl) & ElemenKerja \\
\hline 1 & 28,9 & $1-3$ \\
\hline 2 & 10,4 & $4-6$ \\
\hline 3 & 21,3 & 7 \\
\hline 4 & 20,4 & $8-9$ \\
\hline 5 & 248,4 & $10-11$ \\
\hline
\end{tabular}

Perhitungan efisiensi lintasan dan balance delay pada kondisi awal:

1. Perhitungan Efisiensi Lintasan

Langkah-langkah perhitungan:

a. Mencari waktu siklus yang telah ditetapkan pada saat penelitian, yaitu waktu proses pada stasiun kerja yang terbesar: $T_{c}=\operatorname{Max} T_{s i} \rightarrow T_{c}=248,4 \mathrm{dt}=4,14$ menit

Contoh: Dari stasiun kerja 1 sampai 5 waktu siklus kerja terbesar pada stasiun kerja 5 yaitu 248,4 detik $=4,14$ menit.

b. Bagi siklus masing - masing stasiun kerja dengan waktu siklus terbesar Contoh :

a. Pada stasiun kerja 1

Waktu siklus stasiun $1=28,9 \mathrm{dt}$

Waktu siklus terbesar $\quad=248,4 \mathrm{dt}$

Efisiensi lintasan stasiun $1=\frac{28,9}{248,4}$

$=11,63 \%$

b. Pada stasiun kerja keseluruhan

$$
\begin{array}{ll}
\text { Total waktu siklus } & =369,3 \\
\text { Total waktu siklus } & =1242 \\
\text { Efisiensi lintasan keseluruhan } & =\frac{329,4}{1242} \\
& =26,52 \%
\end{array}
$$

2. Perhitungan Balance Delay

Dengan mengetahui waktu siklus terbesar, maka dapat diperoleh besarnya penundaan keseimbangan (balance delay) pada jalur produksi yaitu dengan persamaan:

Contoh:

$$
d=\frac{n \times T_{c}-T_{w c}}{n \times T_{c}}
$$

a. Pada Stasiun Kerja 1

$$
d=\frac{1 \times 248,2-28,9}{1 \times 248,4}=88,37 \%
$$

b. Pada Stasiun Kerja Keseluruhan

$$
d=\frac{5 \times 248,4-329,4}{5 \times 248,4}=73,48 \%
$$

Adapun hasil, sebagaimana tampak pada Tabel 6, dapat diterangkan sebagai berikut.

1. Efisiensi lintasan $=26,52 \%$

2. Balance delay $=73,48 \%$

Jumlah Stasiun $=5$ stasiun kerja 
Tabel 6. Efisiensi lintasan dan balance delay stasiun kerja pada kondisi awal

\begin{tabular}{lrrrr}
\hline Stasiun Kerja & $\begin{array}{c}\text { Waktu } \\
\text { siklus (dt) }\end{array}$ & $\begin{array}{c}\text { Waktu Siklus } \\
\text { Terbesar }\end{array}$ & $\begin{array}{c}\text { Efiseinsi } \\
\text { Lintasan (\%) }\end{array}$ & $\begin{array}{c}\text { Balance } \\
\text { Delay }(\%)\end{array}$ \\
\hline 1 & 28,9 & 248,4 & 11,63 & 88,37 \\
2 & 10,4 & 248,4 & 4,19 & 95,81 \\
3 & 21,3 & 248,4 & 8,57 & 91,43 \\
4 & 20,4 & 248,4 & 8,21 & 91,79 \\
5 & 248,4 & 248,4 & 100 & 0 \\
\hline Total & 329,4 & 1242 & 132,6 & 367,4 \\
\hline Rerata & 65,88 & 248,4 & 26,52 & 73,48 \\
\hline
\end{tabular}

\section{Precedence Diagram pada Kondisi Awal}

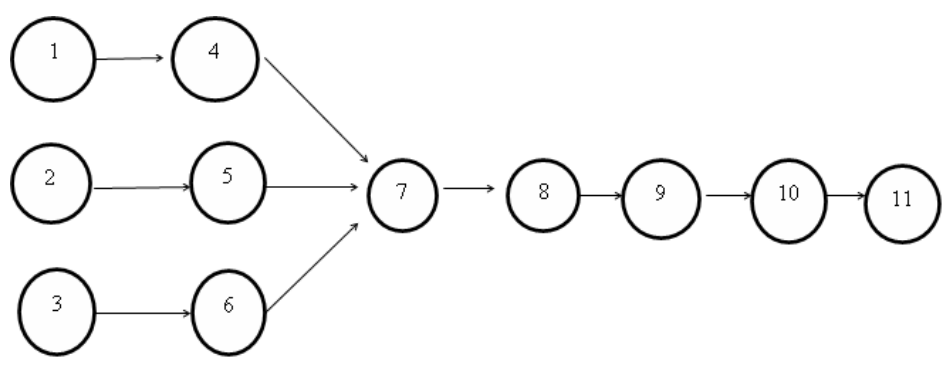

Gambar 4. Precedence diagram

Tabel 7. Daftar kendala tata urutan

\begin{tabular}{lll}
\hline No. & $\begin{array}{l}\text { Kegiatan yang } \\
\text { mendahului }\end{array}$ & $\begin{array}{l}\text { Kendala yang } \\
\text { didahului }\end{array}$ \\
\hline 1 & 1 & 4 \\
2 & 2 & 5 \\
3 & 3 & 6 \\
4 & 4 & 7 \\
5 & 5 & 7 \\
6 & 6 & 7 \\
7 & 7 & 8 \\
8 & 8 & 9 \\
9 & 9 & 10 \\
10 & 10 & 11 \\
\hline
\end{tabular}

Hasil Akhir yang Dicapai dari Penyeimbangan Lintasan Stasiun Kerja dengan Metode RPW

Dari hasil yang dicapai melalui metode Ranked Position Weight (RPW), maka pemecahan masalah keseimbangan lintasan produksi rokok Dji Sam Soe adalah:

1. Waktu pengerjaan antarstasiun kerja lebih merata sehingga keseimbangan lintasan stasiun kerja lebih meningkat.

2. Meningkatkan efisiensi lintasan dari kondisi awal perusahaan yaitu dari $26,52 \%$ naik menjadi $68,54 \%$ serta ditunjukan dengan balance delay yang lebih kecil dibanding dengan pengaturan selama ini yang dijalankan perusahaan dari $73,48 \%$ turun menjadi $31,46 \%$.

3. Analisis keseimbangan lintasan stasiun kerja produksi rokok Dji Sam Soe dengan metode RPW sesuai Gambar 4 adalah layak uji terhadap pengaturan lintasan produski yang selama ini dijalankan oleh perusahaan. 


\section{KESIMPULAN}

Dari data-data yang diambil kemudian dilakukan pengolahan data dalam memecahkan suatu masalah, maka dapat diambil beberapa kesimpulan:

1. Pada susunan stasiun kerja kondisi awal, efisiensi rata-rata stasiun kerja adalah $26,52 \%$. Dengan melakukan penyeimbangan lintasan menggunakan metode RPW, efisiensi rata-rata stasiun kerja meningkat menjadi $68,54 \%$.

2. Pengaturan lintasan produksi yang diterapkan oleh perusahaan selama ini mengakibatkan ketidakseimbangan (balance delay) sebesar $73,48 \%$.

3. Pengaturan keseimbangan lintasan dari hasil analisa pemecahan masalah dengan menggunakan metode RPW dapat mengurangi atau memperkecil ketidakseimbangan (balance delay) sebesar $42,02 \%$ sehingga menjadi $31,46 \%$.

Beberapa saran yang perlu disampaikan berdasarkan pengamatan selama ini yaitu:

1. Perusahaan harus secara berkala melakukan perhitungan efisiensi lintasan produksi dan hasilhasil yang diperoleh dari analisa pemecahan masalah dengan metode line balancing.

2. Perlu diadakan pelatihan untuk melakukan pembagian tugas guna mendapatkan efisiensi lintasan yang tinggi dan balance delay yang rendah.

3. Perlu kiranya perusahaan menekankan program spesialis operator yaitu skill, effect, condition, dan consistency agar mendapatkan operator yang mempunyai performance rating di atas normal pada stasiun kerja sehingga produksi dapat berjalan dengan lancar.

4. Faktor kelonggaran (allowance time) dapat diperkecil apabila perusahaan memberi rasa nyaman pada tempat kerja khususnya temperatur kerja yang selama ini sangat panas dan udara sangat sulit masuk karna ventilasi sangat kurang.

\section{DAFTAR PUSTAKA}

[1] Carcano, E. and Portioli, S., 2014. Integrating Inspection-Policy Design in Assembly-Line Balancing. International Journal of Production Research. 44(18-19), pp.4081-4103.

[2] Ginting, R., 2007. Sistem Produksi. Yogyakarta: Graha Ilmu.

[3] Grzechca, W., 2011. Cycle Time in Assembly Line Balancing Problem. Journal of Industrial Engineering. 22, pp. 171-174.

[4] Nasution, A. H., 2009. Perencanaan dan Pengendalian Produksi, Institut Teknologi Sepuluh Nopember. Surabaya.

[5] Dilworth, J. B., 2013. Production and Operation Management. 5th Edition. Singapore: McGraw-Hill.

[6] Wigjosoebroto, S., 2009. Teknik Tata Cara dan Pengukuran Kerja, Jakarta: Guna Widya.

[7] Elwood, S. B., 2003. Modern Production : Operation Management 7. New York: John Willey and Sons.

[8] Sutalaksana, I. Z., et.al., 2005. Teknik Tata Cara Perbaikan Keseimbangan Lintasan. MTI. Institut Teknologi Bandung, Bandung.

[9] Ghosh, R. J., 2014. A comprehensive literature review and analysis of the design, balancing and scheduling of assembly systems. International Journal of Production research. 27(4).

[10] Sawyer, J. H. F., 2001. Line Balancing. London: The Machinery Publishing co. Ltd.

[11] Merengo, C., Nava, F. and Pozzetti, A., 1999. Balancing and sequencing manual mixed-model assembly lines. International Journal of Production Research, 37(12), pp.2835-2860. 
- Halaman ini sengaja dikosongkan - 